Trakya Eğitim Dergisi

Cilt 10, Say 3

Eylül 2020, 933-949

Geliș Tarihi: 23.12 .2019

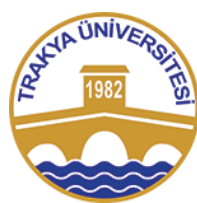

ISSN: $2630-6301$

Doi: $10.24315 /$ tred.663565

Araştırma Makalesi

Research Article
Trakya Journal of Education

Volume 10, Issue 3

September 2020, 933-949

Yayına Kabul Tarihi:08.09.2020

\title{
Öğretmen Adaylarının Gdo'lara Yönelik Bilgi, Tutum Ve Kabul Etme Durumları Arasındaki İlişki ${ }^{1}$
}

\section{The Relationship Between Knowledge of, Attitudes Toward and Acceptance of Genetically Modified Organisms of Pre-Service Elementary School Teachers}

\section{İdris AKTAŞ ${ }^{2}$}

ÖZ: Bu çalıșmanın amacı sınıf öğretmeni adaylarının Genetiği Değiştirilmiş Organizma (GDO)'lara yönelik bilgi, tutum ve kabul etme durumlarını belirleyerek bu değişkenler arasındaki ilişkiyi tespit etmektir. Tarama modelinde gerçekleştirilen çalışma, uygun örnekleme yöntemine göre seçilen ve 2. sınıfa devam eden 67 sınıf öğretmeni adayı ile yürütülmüştür. Veri toplama araçları olarak; kişisel bilgi formu, bilgi, tutum ve kabul etme durumu olmak üzere üç bölümden oluşan GDO ölçeği ve GDO açık uçlu anket formu kullanılmıştır. Verilerin analizinde öncelikle mevcut durumu belirlemek amaciyla betimsel istatistikler kullanılmıştır. Daha sonra öğrencilerin bilgi, tutum ve kabul etme durumları arasındaki ilişkiyi tespit etmek amacıyla Pearson korelasyon analizi kullanılmıştır. Son olarak GDO açık uçlu sorularına verilen cevaplar içerik analizine tabi tutulmuştur. Bulgular adayların bilgi, tutum, kabul etme durumları ve ilgilerinin düşük düzeyde olduğunu göstermiştir. Ayrıca adayların tutum ve kabul etme durumları arasında anlamlı bir iliş̧ki bulunurken bilgi düzeyleri arasında bulunmamıştır. Sonuçlar adayların biyoteknoloji uygulamalarıla birlikte GDO hakkında bilgilendirilmesi gerektiğini ortaya koymuştur.

Anahtar sözcükler: Bilgi, GDO, kabul etme, sinıf ögretmeni adayları, tutum.

Bu makaleye atıf vermek için: 10(3), 933-949.

Aktaş, İ. (2020). Öğretmen adaylarinin GDO’lara yönelik bilgi, tutum ve kabul etme durumlari arasindaki ilişki. Trakya Eğitim Dergisi,

Cite this article as:

Aktas, I. (2020). The relationship between knowledge of, attitudes toward and acceptance of genetically modified organisms of preservice elementary school teachers. Trakya Journal of Education, 10(3), 933-949.

\section{Introduction}

\section{EXTENDED ABSTRACT}

Recent advances in genetics have led to a variety of biotechnology applications such as genetic engineering, rearranged DNA technology, gene cloning, remediation or reproduction. These applications have made biotechnology one of the most rapidly developing, changing and exciting and reactive fields of science and technology. The production of GMO products has become a highly controversial issue based on the benefits and harms that have a direct impact on human life. However, in the studies carried out on GMO products which are getting more and more place in life, it was determined that the knowledge and attitudes of the societies about GMO have changed according to the countries where they live.

\footnotetext{
${ }^{1}$ Bu çalışmanın bir bölümü 21-22 Aralık 2019 tarihlerinde Rize'de gerçekleştirilen III. Ulusal Biyoloji Eğitimi Kongresi'nde sözlü bildiri olarak sunulmuştur.

${ }^{2}$ Dr., Amasya Üniversitesi, Eğitim Fakültesi, Temel Eğitim Bölümü, idrisaktasdr@gmail.com, ORCID: https://orcid.org/0000-00016265-6337
} 
In our country, the opinions of consumers, university students, high school students and elementary school students about GMOs have been tried to be determined by using various measurement tools. While the studies conducted with pre-service teachers, mostly pre-service science teachers, the studies conducted with pre-service elementary school teachers are quite limited. Although there have been many studies about GMOs, it is seen that the society does not have enough information because of false information. However, no study examining the participants' acceptance status of the various products resulting from biotechnology applications was found. In addition, previous studies have focused more on GMO food products that have emerged as a result of biotechnology applications. In this study, biotechnology applications; the animals that have been produced / can be produced, organs for transplantation and cloning are considered as a wider field of application.

As a result of biotechnology applications, GMO products have become a subject of interest to the whole society by increasing the usage area and the number of produced products. Therefore, the opinions of the pre-service elementary school teachers about GMOs are more important in terms of having the right information and attitudes of the students who started the first level of education as well as informing the society correctly through these students.

\section{Method}

The aim of this study is to determine the relationship between knowledge of, attitudes toward and acceptance of Genetically Modified Organism (GMO)'s of pre-service elementary school teachers. The study was carried out with 67 pre-service elementary school teachers who were selected according to the convenience sampling method. As data collection tools; demographic information, GMO scale consisted of three-part that knowledge, attitudes and acceptance and GMO open-ended questionnaire were used. Descriptive statistics were first used to analyze the data. Pearson correlation analysis was used to determine the relationship between knowledge, attitude, acceptance of pre-service teachers.

\section{Findings}

In the study, it was found that the pre-service teachers had medium information about basic knowledge of genetics and did not have enough information about modern biotechnology applications and the harm and benefits of these technologies to humans and the environment, and they had incorrect information in some items. Also, pre-service teachers' general attitudes towards GMOs and sub-dimensions except attitudes towards education were found as low. Attitude scores towards education were found as high. It was determined that the general acceptance status of the pre-service teachers was low, and the acceptance status of GMO plants was slightly higher than GMO microorganisms and animals. In other words, pre-service teachers do not generally accept the use of GMO products. The low level of knowledge and attitudes of pre-service teachers is consistent with the findings of the previous study. While there was a relationship between the average scores of total attitude and total acceptance of GMOs, there was no statistically significant relationship between total knowledge and total attitude and total knowledge and total acceptance scores.

\section{Discussion and Conclusion}

This finding shows that pre-service teachers making decisions about GMOs, they consider underresearched and ear-filling information rather than scientific information. Pre-service teachers consider GMOs as most risky due to the harm they cause to human health but think that some GMO products are acceptable because of the idea that they will be beneficial in the treatment of diseases in the field of medicine and in meeting the food needs in places where food scarcity is experienced. However, it was found that the pre-service teachers identified the GMO mostly with vegetable foods.

Possible reasons for the low level of knowledge, attitudes and acceptance of pre-service teachers are; they may see GMO limited to vegetable foods, which are also revealed by qualitative findings, have low interest and obtain information about GMOs from the environment such as internet and TV programs. These possible situations have caused the pre-service teachers not being able to obtain healthy information as well as have incorrect information about GMOs. The fact that the attitude scores towards education are high, in other words, expressing their needs for information, supports these reasons. In addition, the low level of knowledge of the pre-service teachers and the fact that more than half of the pre-service teachers have incorrect information in some items support the need for a scientific education about GMOs. 


\section{GİRIS}

Son yıllarda genetik alanında meydana gelen gelişmeler genetik mühendisliği, yeniden düzenlemiş DNA teknolojisi, gen klonlama, iyileştirme veya yeniden üretim amaçli klonlama gibi çeşitli biyoteknoloji uygulamalarını doğurmuştur. Bu uygulamalar biyoteknoloji alanını, bilim ve teknolojinin en hızlı gelişen, değişen ve heyecan veren, aynı zamanda tepki oluşturan alanlarından biri haline getirmiştir. Hâlihazırda başarılmış veya gelecekte ulaşılabilecek yeni bulgu veya ürünler sadece bilim insanları arasında değil toplum içinde de bazen endişe bazen de heyecan oluşturacak şekilde merak uyandırmaktadır (Sorgo \& Ambrozic-Dolinsek, 2009). Biyoteknoloji, Genetiği Değiştirilmiş Organizma (GDO) gibi hem toplumun hem de bilim insanlarının bakış açılarının ortaya konulduğu tartışmalı konular sosyobilimsel konular olarak adlandırılmaktadır (Sadler \& Zeidler, 2005). Toplumun biyoteknoloji uygulamalarını, süreçlerini, bilim ilkelerini anlama konusundaki bilgi eksiklikleri, onların bazı sosyobilimsel konular hakkında endişelenmelerine neden olmaktadır (Alberts \& Labov, 2003). Bununla birlikte etik, inanç, ekonomi, çevresel sorumluluk, riskler, politika, eğitim düzeyi gibi değişkenler de biyoteknoloji uygulamalarıyla yeni ürünlerin üretilmesini, sanayi ve ilaç alanlarına aktarılmasını etkilemektedir (Lazarowitz \& Bloch, 2005). Bu nedenlerle sosyobilimsel bir konu olarak biyoteknoloji ve ürün olarak GDO'lar toplum içerisinde oldukça tartışmalı bir konu olma özelliğini devam ettirmektedir.

Biyoteknoloji uygulamaları sonucunda canlıların/organizmaların gen dizilimlerini değiştirerek var olan özellikleri yerine yeni özellikler kazandırılan organizmalara genetiği değiştirilmiş organizmalar denilmektedir (Oğur, Aksoy, \& Y1lmaz, 2017). GDO'lar bitki ve hayvanlarda besin içeriğini zenginleştirmek amacıyla gıda sektöründe (Dawe, Robertson, \& Unnevehr, 2002), patojen (hastalık yapan) mikroorganizmaların çeşitli proteinlerini sentezleyen genlerinin bazı gıdalara aktarılarak etkin aşılamada, bazı gıdaların alerjik reaksiyonlarını azaltmak amacıyla alerjiye neden olan genlerin çıkarılması veya değiştirilmesinde, yine gıdaların genleri değiştirilerek tedavi amaçlı yeni gıdaların üretilmesinde kullanılmaktadır. Ayrıca meyvelerin erken olgunlaşması, raf ömrünün uzatılması, tadının iyileştirilmesi amacıyla da kullanılmaktadır (Oğur ve diğ., 2017). Elverişsiz ortamlara uyum sağlayabilen yeni ürünlerin yetiştirilmesinde, çeşitli organların üretiminde ve böceklerin veya mikroorganizmaların zararlı etkilerine karşı dayanıklı tarım ürünlerinin üretiminde kullanılmaktadır.

GDO'lu ürünlerin üretilmesi, insan hayatına doğrudan etki eden faydaları ve zararları temelinde oldukça tartışmalı bir konu haline gelmiştir. GDO'lu ürünlerin, hızla artan dünya nüfusunun gıda ve ilaç ihtiyaçlarının karşılanmasında, bitkisel ve hayvansal gıdaların veriminin arttırılmasında, insan hastalıklarının tedavi edilmesinde, organ nakillerinin gerçekleştirilmesinde, aşı ve ilaç üretiminde ve hastalık yapan böceklere dirençli bitkisel ürünlerin üretiminde faydalı olacağı düşünülmektedir. Buna karşın besinlerin içerik kalitesinin düşmesi, alerjik reaksiyonlara neden olan ürünlerin oluşması, insan sağlığına olumsuz etkileri, GDO'lu ürünlerin etiketlenmesine yönelik kaygılar, çevreye ve doğaya vereceği zararların ekosistemi olumsuz etkilemesi, dini ve ahlaki olarak bazı çevrelerce kabul görmemesi de olumsuz etkiler olarak görülmektedir (Çelik \& Turgut-Balık, 2007).

Biyoteknoloji uygulamalarında meydana gelen hızlı gelişmeler sonucunda toplum daha fazla GDO'lu ürünlerle karşılaşmakta ve karar verme sürecine girmeye zorlanmaktadır (Hanegan \& Bigler, 2009). Bazı üretici firmalar, tarım üreticileri, bilimsel kurumlar, uzman kamu kuruluşları GDO'ya yönelik ürünlerin üretimi ve yaygınlaşmasını desteklerken; organik tarım destekçileri, çevreciler, bazı politikacı ve akademisyenler olumsuz görüşe sahiptir (Tiryaki, 2007, Akt. Oğur ve diğ, 2017). GDO'lar, teknolojik açıdan getirdiği faydalara karşın doğa ve insan üzerinde oluşturduğu zararlardan dolayı oldukça tartışmalı bir konu olmaya devam etmektedir. Yeni nesli bu konuda bilinçlendirmek amacıyla okul müfredatlarında biyoteknoloji konularına yer verilmiştir (Hanegan \& Bigler, 2009). Buna rağmen gerek ülkemizde gerekse uluslararası alanda yürütülen çalışmalar öğrencilerin hâlâ biyoteknoloji ve GDO hakkında yeterli düzeyde bilgiye sahip olmadığı gibi yanlış bilgiye sahip olduklarını ortaya koymaktadır (Dawson, 2007; Prokop, Leskova, Kubiatko, \& Diran, 2007; Uşak, Erdogan, Prokop, \& Özel, 2009). Bununla birlikte alanyazında toplumların yaşadığı ülkelere göre GDO hakkında bilgi ve tutumlarının değişiklik gösterdiğini ortaya koyan çalışmalar da mevcuttur (Februhartanty, Widyastuti, \& Iswarawanti, 2007; Christoph, Bruhn, \& Roosen, 2008). Türkiye'de ise toplumun GDO'lu ürünler 
hakkında hâlâ yeterli bilgiye sahip olmadığı tespit edilmiştir (Gürbüzoğlu-Yalmanc1, 2016; Oğur ve diğ., 2017; Özel, Erdoğan, Uşak, \& Prokop, 2009; Uzunkol, 2012; Yılmaz, Üner, \& Ercan, 2015).

Son yıllarda ulusal basın, bazı yazarlar, çevreciler, üniversiteler aracılı̆̆ıyla toplum GDO'nun getirdiği faydalarla birlikte zararları hakkında bilgi sahibi olmaya başlamıştır (Tiryaki, 2007, Akt. Oğur ve diğ., 2017). Ülkemizde gerek tüketicilerin (Hıdıroğlu, Önsüz, Kalafat, \& Karavuş, 2013; HaspolatKaya, Konar, Poyrazoğlu, \& Artık, 2013; Taş, Balcı, Yüksel, \& Şahin-Yesilçubuk, 2015), gerek üniversite öğrencilerinin (Adana, Gezer, \& Ögüt, 2014; Akçay, 2017; Ergin, Uzun, \& Bozkurt, 2015; Koçak, Türker, Kılıç, \& Hasde, 2010; Merdan, 2019; Özdemir, Güneş, \& Demir, 2010; Uzunkol, 2012; Yılmaz ve diğ., 2015), gerek lise öğrencilerinin (Özel ve diğ., 2009; Gürbüzoğlu-Yalmanc1, 2016) gerekse ilköğretim öğrencilerinin (Bilen \& Özel, 2012; Özden, Akgün, Çinici, Gülmez, \& Demirtaş, 2013) GDO hakkındaki görüşleri çeşitli ölçme araçları kullanılarak tespit edilmeye çalışılmıştır. Öğretmen adaylarıyla yürütülen çalışmalar çoğunlukla fen bilgisi öğretmen adaylarıyla yürütülürken (Çankaya \& Filik-İş̧en, 2015; Sönmez \& K1lınç, 2012; Uysal, Cebesoy, \& Karışan, 2018) sınıf öğretmeni adaylarıyla yürütülen çalışmalar oldukça sınırlıdır (Uzunkol, 2012). Ayrıca alanyazında katılımcıların GDO'lar ile ilgili bilgi düzeylerini ve görüşlerini ortaya koymayı amaçlayan birçok çalışmaya rastlanılmasına rağmen biyoteknoloji uygulamaları sonucunda ortaya çıkan çeşitli ürünleri kabul etme durumlarını inceleyen çalışmaya rastlanılmamıştır. Ayrıca önceki çalışmalarda daha çok biyoteknoloji uygulamaları sonucu ortaya çıkan GDO'lu gıda ürünleri üzerine odaklanılmıştır. Bu çalışmada ise biyoteknoloji uygulamaları; üretilen/üretilebilecek hayvanları, nakil için organları, klonlamaları içeren daha geniş bir uygulama alanı olarak ele alınmış ve olası durumlar üzerinde de durulmuştur.

Biyoteknoloji uygulamalarının sonucu olarak ortaya çıkan GDO'lu ürünler, zaman içerisinde hem kullanım alanının genişlemesi hem de üretilen ürün sayısının artmasıyla birlikte sadece fen bilimlerinin veya bilim insanlarının ilgilendiği bir konu olmaktan çıkmış, tüm toplumu ilgilendiren bir konu haline gelmiştir. Bu nedenle toplumla daha fazla iç içe olan sınıf öğretmeni adaylarının GDO hakkındaki düşünceleri hem eğitimin ilk kademesine başlayan öğrencilerin GDO ve uygulamaları ile ilgili doğru bilgi ve tutuma sahip olmaları hem de bu öğrencilerin aracılı̆̆ıyla toplumun doğru bilgilendirilmesi bakımından önemlidir. Bu bağlamda bu çalışmanın genel amacı sınıf öğretmeni adaylarının genetiği değiştirilmiş organizmalara yönelik bilgi, tutum ve kabul etme durumlarını belirleyerek bu değişkenler arasındaki ilişkiyi ortaya koymaktır. Bu amaç doğrultusunda aşağıdaki araştırma sorularına sırayla cevaplar aranmıştır.

1. Sınıf öğretmeni adaylarının genetiği değiştirilmiş organizmalara yönelik bilgi düzeyleri nedir?

2. Sınıf öğretmeni adaylarının genetiği değiştirilmiş organizmalara yönelik tutum düzeyleri nedir?

3. Sınıf öğretmeni adaylarının genetiği değiştirilmiş organizmalara yönelik kabul etme düzeyleri nedir?

4. Sınıf öğretmeni adaylarının genetiği değiştirilmiş organizmalara yönelik bilgi, tutum ve kabul etme düzeyleri arasında bir korelasyon var mıdır?

5. Sınıf öğretmeni adaylarının genetiği değiştirilmiş organizmalara yönelik görüşleri nelerdir?

\section{YÖNTEM}

\section{Araştırmanın Modeli}

Çalışma, sınıf öğretmeni adaylarının genetiği değiştirilmiş organizmalarla ilgili bilgi, tutum ve kabul etme durumları ve görüşlerine yönelik mevcut durumlarını tespit ederek bu değişkenler arasındaki ilişkiyi ortaya koymayı amaçladığından tarama modelinde korelasyonel bir çalışmadır (Fraenkel, Wallen, \& Hyun, 2012). 


\section{Araștırmanın Örneklemi}

Araştırmacılar, çalışmalarının amaçlarına hizmet edecek ve kolay ulaşabilecekleri örneklemlerle çalışacakları durumlarda uygun örnekleme yöntemini tercih ederler (Yıldırım \& Şimşek, 2011). Bu çalışmanın örneklemini Türkiye'nin kuzeyinde bir il merkezindeki bir üniversitede uygun örnekleme yöntemine göre seçilen ve 2. sınıfa devam eden 67 (48 kadın, 19 erkek) sınıf öğretmeni adayı oluşturmuştur. Adayların, okulu dikkate almadığımızda, bazıları birden fazla kaynaktan olmak üzere $49(\% 73,1)$ 'u internet, 43 (\%64,2)'ü televizyon, 13 (\%19,4)'ü aile, 7 (\%10,4)'si arkadaş çevresi ve 6 (\%9)'sı gazeteden GDO hakkında bilgi edinmiştir. Adayların biyoteknoloji ve GDO'ya yönelik ilgi düzeyleri ise kendilerini 1 ile 5 arasında değerlendirdikleri maddede ortalama \%33,25'lük oran ile oldukça düşük düzeydedir.

\section{Veri Toplama Araçları ve Uygulama Süreci}

Veri toplama aracı olarak kişisel bilgi formu ile bilgi, tutum ve kabul etme durumu olmak üzere 3 bölümden oluşan $G D O$ ölçeği kullanılmıştır. Ayrıca sınıf öğretmeni adaylarının GDO'ya yönelik görüşlerini belirlemek amacıyla açık uçlu anket formu kullanılmıştır. Kullanılan veri toplama araçlarıyla ilgili aşağıda detaylı bilgiler verilmiştir.

Kişisel Bilgi Formu: Adayların cinsiyetleri, GDO hakkında bilgiyi elde ettiği kaynaklar ve GDO’ya yönelik ilgi düzeylerini tespit etmek amacıyla araştırmacı tarafından geliştirilen bir kişisel bilgi formu kullanılmıştır.

Genetiği Değiştirilmiş Organizmalar Ölçeği: Ölçek GDO'ya yönelik bilgi, tutum ve kabul etme olmak üzere üç bölümden oluşmaktadır. Orijinali Sorgo ve Ambrozic-Dolinsek (2009) tarafından geliştirilmiştir. Türkçeye uyarlaması ise Aktaş (2019) tarafından yapılmıştır. Uyarlama çalışması geri çeviri (back- translation) yöntemi kullanılarak yapılmıştır. Geri çeviri yöntemi öncelikle hedef dile çevrilen bir ölçeği tekrar orijinal dile çevirerek formlar arasında uyum sağlama sürecidir (Miyabe \& Yoshino, 2015). Ölçek uyarlama sürecinde sırasıyla aşağıdaki adımlar takip edilmiştir (Çapık, Gözüm, \& Aksayan, 2018; Miyabe \& Yoshino, 2015). Orijinal ölçek öncelikle araştırmacı ve bir İngilizce öğretmeni tarafından ayrı ayrı Türkçeye çevrilmiştir. İkinci olarak bu iki çevirmenin bir araya gelmesiyle yapılan iki çeviri arasındaki uyuma bakılmış ve tartışmalar sonunda varılan fikir birliğiyle iki çeviri tek çeviriye indirgenmiştir. Üçüncü olarak fen eğitimi alanında çalışan bir uzman tarafından Türkçeye çevrilen ölçek tekrar İngilizceye çevrilmiştir. Dördüncü olarak araştırmacı orijinal form ile İngilizce çeviri formunu karşılaştırmış ve ihtiyaç duyulan yerlerde İngilizce öğretmeni ve uzmana danışarak anlam birliğini sağlamıştır. Son olarak pilot çalışma için maddelerin anlaşılırlığını test etmek amacıyla Türkçe form 3 sınıf öğretmeni adayına uygulanarak ölçeğe nihai hali verilmiştir. Ölçme aracının güvenirliğini belirlemek için 186 öğretmene uygulayan Sorgo ve Ambrozic-Dolinsek (2009), Cronbach's alpha katsayısını bilgi bölümü için 0.912, tutum bölümü için 0.867 ve kabul etme bölümü için 0.905 olarak bulmuştur. Yapılan bu çalışmada ise Cronbach's alpha katsayıları bilgi bölümü için 0,871 , tutum bölümü için 0,747 ve kabul etme bölümü için ise 0,835 olarak hesaplanmıştır. GDO'ya yönelik bilgi bölümü; "doğru”, "bilgim yok" ve "yanlış" olmak üzere üç seçenekli 30 maddeden oluşmaktadır. Bu maddelerin 12'si ortaokul son sinıf ve lise düzeyinde öğretilen klasik GDO bilgisini ölçmeye yöneliktir. 18'i ise biyoteknoloji ve uygulamalarını içeren modern GDO bilgisini ölçmeye yöneliktir. Bilgi maddeleri ölçeğin cevaplama güvenirliğini arttırmak amacıyla ölçekte rastgele dağıtılan 13 olumsuz ve 17 olumlu maddeden oluşmaktadır. Ölçeğin GDO'ya yönelik tutum bölümü; "kesinlikle katılmıyorum" ile "kesinlikle katılıyorum" arasında değişen 5'li likert tarzında 28 maddeden oluşmaktadır. Tutum ölçeği; sağlık-tıp uygulamaları (6 madde), besin uygulamaları (5 madde), tarım uygulamaları ( 8 madde), eğitim (4 madde) ve toplum-bilimsel araştırma uygulamaları (5 madde) olmak üzere 5 alt boyuttan oluşmaktadır. Tutum bölümünden alınabilecek en yüksek puan 140 iken en düşük puan 28'dir. Ölçeğin GDO kabul etme bölümü; "doğru”, "bilgim yok" ve "yanllş" olmak üzere üç seçenekli 17 maddeden oluşmaktadır. Adayların GDO kabul etme bölümü mikroorganizmalar, bitkiler ve hayvanlar olmak üzere 3 alt bölümden oluşmaktadır.

Açık Uçlu Anket Formu: Adayların GDO'ya yönelik bilgilerini derinleştirmek amacıyla araştırmacı tarafından oluşturulan açık uçlu anket formu kullanılmıştır. Açık uçlu form adayların; GDO’lu üründen ne anladıkları, bu ürünlerin hangi alanlarda ve ne amaçla kullanıldığı, faydalı veya zararlı olup olmadığına yönelik sorulardan oluşmaktadır. 
Uygulama Süreci: Veri toplama araçları adaylara 40 dakikalık süre içerisinde araştırmacı kontrolünde tek oturumda uygulanmıştır. Farklı oturumlar olması durumunda oturumlar arasında geçen süre içerisinde oluşabilecek bilgi alışverişini engellemek ve verilen cevapların güvenirliğini arttırmak amacıyla ölçekler ve açık uçlu anket formunun adaylara tek oturumda uygulanması tercih edilmiştir.

\section{Verilerin Analizleri}

Verilerin analizinde adayların bilgi, tutum ve kabul etme durumlarını belirlemek amacıly aritmetik ortalama, standart sapma ve yüzde oran değerleri gibi betimsel istatistikler kullanılmıştır. Bilgi düzeyi, verilen doğru cevap 1 , diğerleri 0 puan verilerek tüm maddelerin toplamıla, kabul etme düzeyi "kabul ederim" maddesine 1 , diğer maddelere 0 puan verilerek tüm maddelerin puanlarının toplamıla tespit edilmiştir. Tutum bölümünde yer alan olumsuz maddeler olumluya çevrilmiş ve her bir maddenin puanı toplanarak elde edilen toplam puan tutum puanını oluşturmuştur. Böylece tutum puanıyla ilgili oluşabilecek en yüksek puan 140, en düşük puan ise $28^{\prime}$ dir. Adayların bilgi, tutum, kabul etme ve ilgi düzeyleri yüksek, orta ve düşük olmak üzere 3 kategoride değerlendirilmiştir. Akkoyunlu, YılmazSoylu ve Çağlar (2010) ölçeklerinde seviye puan aralıklarını oluştururken ölçekten alınabilecek en yüksek ve en düşük puan aralığını eşit aralıklara bölerek seviye aralıklarını belirlemiştir. Bu çalışmada kategorilerin değer aralıkları belirlenirken ölçeklerden alınan puanlar yüzlük sisteme çevrilerek 100 puanı üç aralığa bölünmüştür. Ancak ölçme araçları çoktan seçmeli maddelerden oluştuğundan ve bu durum şans başarısı doğurduğundan düşük kategori aralığı geniş tutulmuştur. Sonuç olarak 0-40 puan aralığı düşük başarı, 40-70 orta başarı ve 70-100 yüksek başarı düzeyi olarak belirlenmiş ve bu aralıklar dikkate alınarak değerlendirmeler yapılmıştır. Daha sonra öğrencilerin bilgi, tutum ve kabul etme durumu arasında bir ilişki olup olmadığını tespit etmek amacıyla Pearson korelasyon analizi kullanılmışıı. Analiz sonucunda elde edilen korelasyon katsayılarının yorumlanmasında 0,00-0,30 düşük, 0,31-0,70 orta ve 0,71-1,00 arası yüksek korelasyon olarak değerlendirilmiştir (Büyüköztürk, 2009).

\section{BULGULAR}

$\mathrm{Bu}$ bölümde araştırma sürecinde elde edilen bulgular araştırma soruları temelinde; sınıf öğretmeni adaylarının GDO bilgi düzeyleri, tutum düzeyleri, kabul etme durumları, adayların bilgi, tutum ve kabul etme durumları arasındaki ilişki ve adayların GDO'ya yönelik görüşleri olmak üzere beş başlık altında sunulmuştur.

\section{Sınıf Öğretmeni Adaylarının GDO Bilgi Düzeyleri}

Sınıf öğretmeni adaylarının GDO bilgi düzeyleri, okullarda öğretilen klasik bilgi ile biyoteknoloji uygulamaları ve topluma etkilerini içeren modern bilgi olmak üzere iki alt boyutta incelenmiştir. Ölçeğin her bir maddesinde yer alan maddelere verilen cevapların frekans, yüzde değerleri Tablo 1'de verilmiştir. Alt boyut ve toplam puanlar doğru cevapların toplamıyla hesaplanmıştır. Öğretmen adaylarının GDO bilgi ölçeğinin alt boyutları ve ölçeğinin toplamından aldıkları puanların ortalama, standart sapma ve yüzde değerleri Tablo 2'de verilmiştir.

Tablo 1.

Sinıf ögretmeni adaylarının GDO bilgi düzeyleri

\begin{tabular}{|c|c|c|c|c|c|}
\hline & \multirow[t]{2}{*}{ GDO Bilgi Maddeleri } & \multirow[t]{2}{*}{$\begin{array}{l}\text { Doğru } \\
\text { Cevap }\end{array}$} & \multirow{2}{*}{$\begin{array}{l}\text { Doğru } \\
\text { n (\%) }\end{array}$} & \multirow{2}{*}{$\begin{array}{c}\begin{array}{c}\text { Bilgim } \\
\text { Yok }\end{array} \\
\text { n }(\%)\end{array}$} & \multirow{2}{*}{$\begin{array}{l}\text { Yanlış } \\
\text { n (\%) }\end{array}$} \\
\hline & & & & & \\
\hline \multirow{6}{*}{ 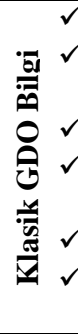 } & Bitkilerin kesilerek ç & $\mathrm{D}$ & $33(49,3)$ & $15(22,4)$ & $19(28,4)$ \\
\hline & $\begin{array}{l}\text { Genler normal yollarla doğada bulunan bir türden doğada } \\
\text { bulunan diğer bir türe geçmez. }\end{array}$ & $\mathrm{D}$ & $31(46,3)$ & $17(25,4)$ & $19(28,4)$ \\
\hline & Mutasyonlar her zaman nesilden nesile aktarılır. & $\mathrm{Y}$ & $33(49,3)$ & $16(23,9)$ & $18(26,9)$ \\
\hline & $\begin{array}{l}\text { Bir kedi, dişi bir tavşanı dölleyebilir; ortaya çıkan genç } \\
\text { tavşanların kulakları daha kısa olur. }\end{array}$ & Y & $24(35,8)$ & $31(46,3)$ & $12(17,9)$ \\
\hline & Çocuğun cinsiyetini erkekten gelen cinsiyet hücreleri belirler. & $\mathrm{D}$ & $10(14,9)$ & $9(13,4)$ & $48(71,6)$ \\
\hline & $\begin{array}{l}\text { Çekinik genler hiçbir zaman organizma üzerinde etkisini } \\
\text { göstermez. }\end{array}$ & Y & $54(80,6)$ & $5(7,5)$ & $8(11,9)$ \\
\hline
\end{tabular}


Tablo 1 (devami).

Sınlf ögretmeni adaylarının GDO bilgi düzeyleri

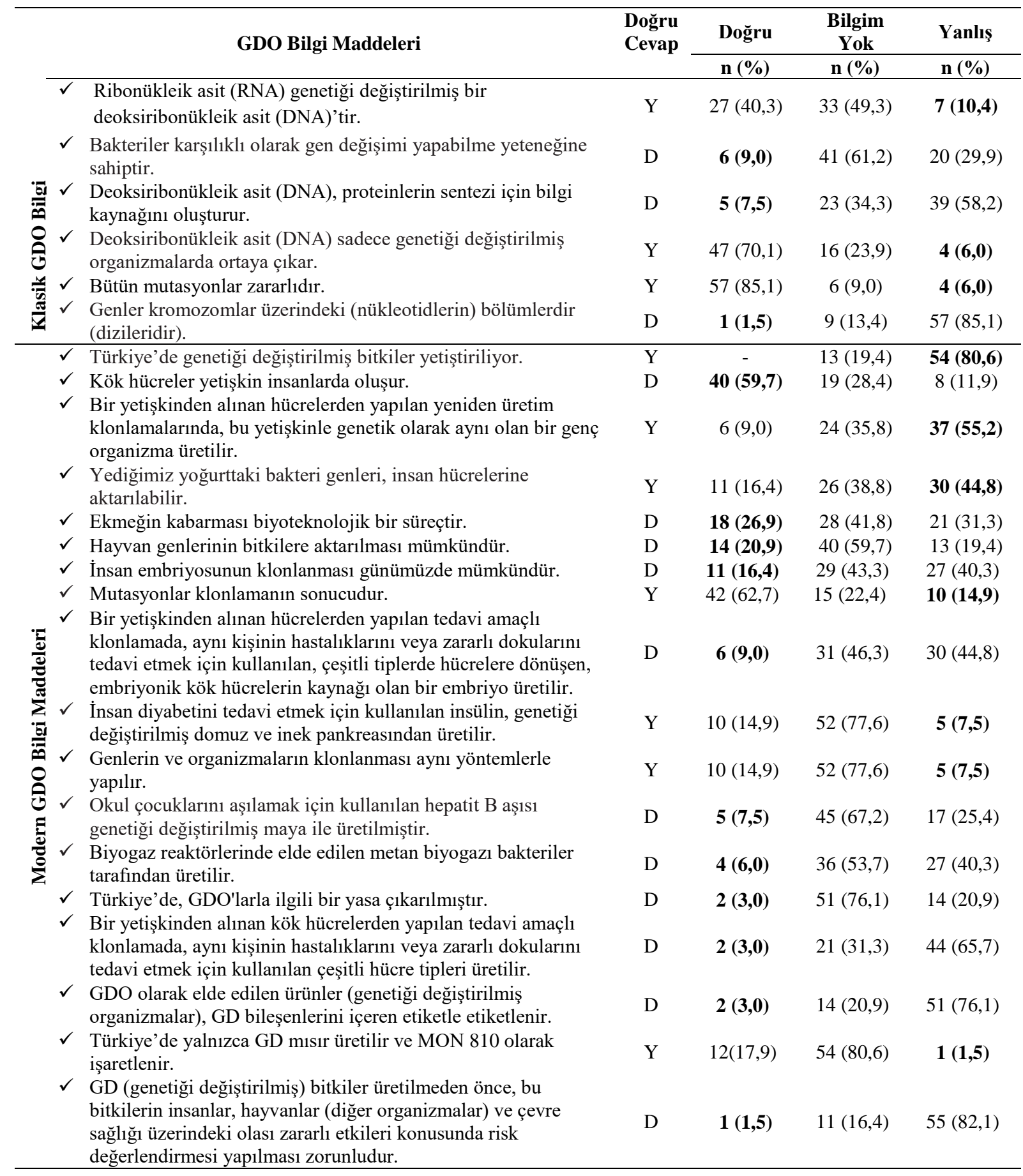

Tablo 1 incelendiğinde 30 maddenin sadece dördünde sınıf öğretmeni adaylarının \%50'si ve daha fazlası doğru cevabı vermiştir. Diğer maddelerde adayların yarısından daha azı doğru cevabı vermiştir. Öğretmen adaylarından klasik GDO maddelerine "bilgim yok" diyenlerin sayısı düşükken modern GDO bilgisinde "bilgim yok" diyenlerin sayısının fazla olduğu dikkat çekmektedir. Modern GDO bilgisinde 18 maddenin 10'unda adayların \%40'indan fazlası, 4'ünde \%75'inden daha fazlası "bilgim yok" şeklinde cevap vermiştir. Ayrıca modern GDO bilgisinde 18 maddenin 10'una adayların \%10'undan daha azı doğru cevap vermiştir. Klasik GDO bilgisinde 12 maddenin 5'inde adayların \%10'undan daha azı doğru cevap vermiştir. En çok bilinen madde Türkiye'de GDO'lu ürünlerin üretimine izin verilmediği, en az bilinen madde ise GDO üretimi için çevreye, hayvanlara, bitkilere ve sağlığa olası zararları hakkında araştırma yapılması zorunluluğunun olduğudur. En fazla dikkat çeken 
bulgular ise adayların bir kedinin dişi bir tavşanı dölleyebileceğini, çocuğun cinsiyetinin erkek cinsiyet hücrelerine bağlı olmadığını, çekinik genlerin hiçbir zaman organizma üzerinde etkisini gösteremeyeceğini düşünmeleri ve gen, DNA kavramlarını ve görevlerini bilmemeleridir.

Tablo 2.

Adayların GDO bilgi ölçeğinin toplamı ve alt boyutlarından aldıkları puanlara ait istatistikler

\begin{tabular}{lcccc}
\hline GDO Bilgi Ölçeği Boyutları & N & X & SS & $\%$ \\
\hline Klasik bilgi & 67 & 6,63 & 2,15 & 55,25 \\
Modern bilgi & 67 & 5,31 & 2,11 & 29,5 \\
Toplam & $\mathbf{6 7}$ & $\mathbf{1 2 , 5 7}$ & $\mathbf{3 , 5 9}$ & $\mathbf{4 1 , 9}$ \\
\hline
\end{tabular}

Tablo 2 incelendiğinde adayların GDO toplam bilgi düzeylerinin $\% 41,9(X=12,57$; SS=3,59) ile düşük düzeye çok yakın olduğu görülmektedir. Bununla birlikte okullarda öğretilen klasik genetik bilgilerinin \%55,25 $(\mathrm{X}=6,63 ; \mathrm{SS}=2,15)$ ile orta düzeyde ve biyoteknoloji ve genetik uygulamalarından oluşan modern GDO bilgilerinin ise $\% 29,5(\mathrm{X}=5,31 ; \mathrm{SS}=2,11)$ ile oldukça düşük düzeyde olduğu tespit edilmiştir. Sınıf öğretmeni adaylarının özellikle modern GDO bilgisi olmak üzere GDO bilgi düzeylerinin düşük düzeyde olduğu görülmüsşür.

\section{Sınıf Öğretmeni Adaylarının GDO Tutum Düzeyleri}

Öğretmen adaylarının GDO tutum ölçeği toplamı ve alt boyutlarından aldıkları puanların ortalama, standart sapma ve yüzde değerleri Tablo 3'te verilmiştir.

Tablo 3.

Adayların GDO tutum ölçeği toplamı ve alt boyutlarından aldıkları puanlara ait istatistikler

\begin{tabular}{lcccc}
\hline GDO Tutum Ölçeği Boyutları & $\mathbf{n}$ & $\mathbf{X}$ & SS & \% \\
\hline Sağlık-tıp uygulamaları & 67 & 15,87 & 2,42 & 41,13 \\
Gıda uygulamaları & 67 & 13,43 & 2,52 & 42,15 \\
Tarım uygulamaları & 67 & 19,11 & 3,99 & 34,72 \\
Eğitime yönelik tutum & 67 & 15,89 & 2,43 & 74,38 \\
Toplum ve bilim araştırmaları tutumu & 67 & 12,94 & 2,68 & 39,70 \\
Toplam Tutum & $\mathbf{6 7}$ & $\mathbf{7 7 , 2 4}$ & $\mathbf{7 , 9 0}$ & $\mathbf{4 3 , 9 6}$ \\
\hline
\end{tabular}

Tablo 3 incelendiğinde adayların toplam tutum puanlarının \%43,96 (X=77,24; SS=7,91) ile orta düzeyde olduğu görülmektedir. Ayrıca adayların GDO'ların sağlık-tıp uygulamaları $\% 41,13(X=15,87$; $\mathrm{SS}=2,42)$, gida uygulamaları \%42,15 (X=13,43; SS=2,52), tarım uygulamaları \%34,72 (X=19,11; $\mathrm{SS}=3,99)$, eğitime yönelik tutum (eğitim ihtiyac1) \%74,38 (X=15,9; $\mathrm{SS}=2,43)$ ile toplum ve bilim araștırmaları tutumu puanlarının \%39,7 (X=12,94; $\mathrm{SS}=2,68)$ oranında olduğu tespit edilmiștir. $\mathrm{Bu}$ bağlamda, GDO hakkında eğitimin verilmesine yönelik tutumlarının yüksek düzeyde, diğer boyutlardaki tutumların ise düşük veya düşüğe çok yakın düzeyde olduğu söylenebilir. Ĕgitime yönelik tutum alt boyutundaki ifadeler öğrencilere gerçeklerle birlikte GDO ile ilgili olarak etik, ahlak ve değeri öğretmeye yöneliktir. Ayrıca bilimsel araştırmalara ve araştırmacılara güvenlerinin düşük düzeyde olduğu görülmüştür. Öğretmen adaylarının en fazla dirençli olduğu maddelerin ise vücuda GDO ürünlerinin alınması ve yiyeceklerin tüketilmesi olduğu tespit edilmiştir.

\section{Sınıf Öğretmeni Adaylarının GDO’lu Ürünleri Kabul Etme Durumları}

Öğretmen adaylarının GDO'lu ürünleri kabul etme ölçeğinin toplamı ve alt boyutlarından aldıkları puanların ortalama, standart sapma ve yüzde değerleri Tablo 4 'te verilmiştir. 
Tablo 4.

Adayların GDO kabul etme ölçeği maddelerinden aldıkları puanlara ait istatistikler

\begin{tabular}{|c|c|c|c|c|}
\hline \multicolumn{2}{|r|}{ GDO’ya Yönelik Kabul Etme Maddeleri } & $\begin{array}{c}\begin{array}{c}\text { Kabul } \\
\text { Edebilirim }\end{array} \\
\mathrm{f}(\%) \\
\end{array}$ & $\begin{array}{c}\begin{array}{c}\text { Kararsı- } \\
\text { zım }\end{array} \\
\mathrm{f}(\%) \\
\end{array}$ & $\begin{array}{c}\text { Kabul } \\
\text { Etmem } \\
\mathrm{f}(\%) \\
\end{array}$ \\
\hline \multirow{5}{*}{ 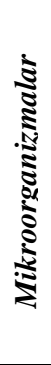 } & $\begin{array}{l}\text { T1bbi maddeleri (örneğin, insülin) sentezleyebilen } \\
\text { mikroorganizmalar }\end{array}$ & $39(58,2)$ & $21(31,3)$ & $7(10,4)$ \\
\hline & $\begin{array}{l}\checkmark \text { Daha önce biyolojik olarak parçalanamayan zehirli veya zararlı } \\
\text { maddeleri bozabilecek mikroorganizmalar }\end{array}$ & $33(49,3)$ & $17(25,4)$ & $17(25,4)$ \\
\hline & $\begin{array}{l}\checkmark \text { Uygulanabilir organik maddeleri (örneğin, çeşitli organik asitleri) } \\
\text { sentezleyebilen mikroorganizmalar }\end{array}$ & $27(40,3)$ & $33(49,3)$ & $7(10,4)$ \\
\hline & $\begin{array}{l}\checkmark \text { Gida endüstrisinde organik sentez (örneğin, biyoetanol) için } \\
\text { kullanılan mikroorganizmalar }\end{array}$ & $16(23,9)$ & $43(64,2)$ & $8(11,9)$ \\
\hline & $\begin{array}{l}\checkmark \text { Organizmalar arasında gen transferi için genetiği değiştirilmiş } \\
\text { virüsler }\end{array}$ & $5(7,5)$ & $34(50,7)$ & $28(41,8)$ \\
\hline \multirow{8}{*}{ 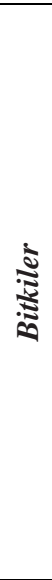 } & $\begin{array}{l}\checkmark \text { Zararlı ve hastalık yapan organizmalara dayanıklı insanların } \\
\text { tüketeceği bitkisel gıdalar }\end{array}$ & $36(53,7)$ & $14(20,9)$ & $17(25,4)$ \\
\hline & $\checkmark$ T1bbi maddeleri sentezleyebilen bitkiler & $34(50,7)$ & $26(38,8)$ & $7(10,4)$ \\
\hline & $\begin{array}{l}\checkmark \text { Zararlı ve hastalık yapan organizmalara dayanıklı hayvanların } \\
\text { tüketeceği bitkisel gıdalar }\end{array}$ & $32(47,8)$ & $21(31,3)$ & $14(20,9)$ \\
\hline & $\begin{array}{l}\checkmark \text { Olumsuz koşullarda (örneğin; tuzlu, kurak ortamlar) bile yetişebilen } \\
\text { bitkisel ürünler }\end{array}$ & $32(47,8)$ & $20(29,9)$ & $15(22,4)$ \\
\hline & $\checkmark$ Yeni özelliklere sahip, bahçe süs bitkileri (örneğin, mavi karanfiller). & $30(44,8)$ & $20(29,9)$ & $17(25,4)$ \\
\hline & $\checkmark$ Biyoyakıt üretiminde kullanılan bitkiler & $29(43,3)$ & $27(40,3)$ & $11(16,4)$ \\
\hline & $\begin{array}{l}\checkmark \text { Yeni özelliklere sahip, evler için süs bitkileri (örneğin, karanlıkta } \\
\text { parlayan süs bitkileri). }\end{array}$ & $28(41,8)$ & $18(26,9)$ & $21(31,3)$ \\
\hline & $\begin{array}{l}\checkmark \text { İnsanların tüketeceği, meyve kalitesi iyileştirilmiş bitkisel gıdalar } \\
\text { (örneğin; soğuk hava depolarında uzun süre tutma, daha yoğun } \\
\text { renklenme gibi). }\end{array}$ & $14(20,9)$ & $22(32,8)$ & $31(46,3)$ \\
\hline \multirow{4}{*}{ 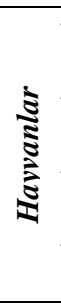 } & $\begin{array}{l}\checkmark \text { GD organ nakli için donör olarak yetiştirilen hayvanlar (zarar } \\
\text { görmüş organ veya dokuları değiştirmek veya onarmak için). }\end{array}$ & $27(40,3)$ & $31(46,3)$ & $9(13,4)$ \\
\hline & $\begin{array}{l}\checkmark \text { Yeni özelliklere sahip evcil hayvanlar (örneğin, dökülmeyen ve } \\
\text { alerjik etki yapmayan tüylere sahip kediler) }\end{array}$ & $27(40,3)$ & $17(25,4)$ & $23(34,3)$ \\
\hline & $\begin{array}{l}\checkmark \quad \text { Tibbi maddeler içeren (örneğin, pıhtılaşma kan faktörü) süt üreten } \\
\text { hayvanlar (örneğin, keçiler) }\end{array}$ & $24(35,8)$ & $36(53,7)$ & $7(10,4)$ \\
\hline & $\begin{array}{l}\checkmark \quad \text { İnsanların tüketeceği, kalitesi iyileştirilmiş etler (örneğin, az yağlı } \\
\text { veya daha yoğun renkli olan etler). }\end{array}$ & $15(22,4)$ & $28(41,8)$ & $24(35,8)$ \\
\hline
\end{tabular}

Adayların GDO'lu bitkileri kabul etme durumlarının hayvanları ve mikroorganizmaları kabul etme durumlarından daha fazla olduğu görülmektedir. Ayrıca adayların GDO'lu ürünleri kabul etmeme durumlarının kabul etme durumlarından daha düşük olduğu ve kararsız kaldığı durumların daha fazla olduğu görülmektedir. Adayların en fazla, GDO'lu ürünleri bitkisel veya hayvansal olarak ayırt etmeksizin besin olarak tüketmeyi kabul etmedikleri görülmektedir.

Öğretmen adaylarının GDO'lu ürünleri kabul etme ölçeğinin alt boyutları ve ölçeğinin toplamından aldıkları puanların ortalama, standart sapma ve yüzde değerleri Tablo 5'te verilmiştir.

Tablo 5 .

Adayların GDO'lu ürünleri kabul etme ölçeği ve alt boyutlarından aldıkları puanlara ait istatistikler

\begin{tabular}{|c|c|c|c|c|c|}
\hline $\begin{array}{l}\text { GDO Kabul Etme } \\
\text { Boyutları }\end{array}$ & Ölçeği & $\mathbf{n}$ & $\mathbf{X}$ & SS & $\%$ \\
\hline Mikroorganizmalar & & 67 & 1,79 & 1,44 & 35,80 \\
\hline Bitkiler & & 67 & 3,51 & 2,39 & 43,88 \\
\hline Hayvanlar & & 67 & 1,39 & 1,18 & 34,75 \\
\hline Toplam Kabul Etme & & 67 & 6,69 & 4,15 & 39,35 \\
\hline
\end{tabular}

Adayların toplam kabul etme durumlarının \%39,35 $(X=6,69 ; \mathrm{SS}=4,15)$ ile düşük düzeyde olduğu belirlenmiştir. GDO'ları kabul etme bölümünün alt boyutları incelendiğinde GDO'lu hayvanları 
\%34,75 (X=1,39; SS=1,18), GDO'lu bitkileri \%43,88 (X=3,51; SS=2,39) ve GDO’lu mikroorganizmaları kabul etme \%35,8 (X=1,79; $\mathrm{SS}=1,44)$ durumlarının düşük veya düşüğe çok yakın düzeyde olduğu tespit edilmiştir. Bu durum adaylar tarafından GDO'lu bitkilerin, hayvanlardan ve mikroorganizmalardan daha kabul edilebilir olduğunu göstermektedir. Diğer taraftan adayların maddelerin çoğunda kabul etmeme durumundan ziyade kararsız oldukları tespit edilmiştir.

\section{Sınıf Öğretmeni Adaylarının GDO Bilgi, Tutum ve Kabul Etme Durumları Arasındaki Korelasyon}

Öğretmen adaylarının GDO bilgi, tutum, kabul etme durumları ve alt boyutları arasında bir ilişki olup olmadığını tespit etmek amacıyla Pearson korelasyon analizi yapılmış ve analiz sonuçları Tablo 6'da verilmiştir.

Tablo 6.

Pearson korelasyonu analiz sonuçları

\begin{tabular}{|c|c|c|c|c|c|c|c|c|c|c|c|c|c|}
\hline Değişkenler & 音 & 志 & 志 & 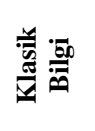 & $\underset{z}{g}$ & 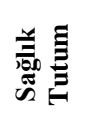 & 䄊声 & 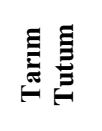 & 罳 & 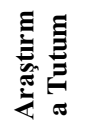 & 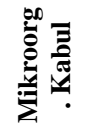 & 言言 & 票 \\
\hline Toplam Bilgi & 1 & & & & & & & & & & & & \\
\hline Toplam Tutum & 0,120 & 1 & & & & & & & & & & & \\
\hline Toplam Kabul &, 002 &, $367^{* *}$ & 1 & & & & & & & & & & \\
\hline Klasik Bilgi &, $823^{* *}$ &, 059 &,- 090 & 1 & & & & & & & & & \\
\hline Modern Bilgi &, $832^{* *}$ &, 139 &, 091 &, $369^{* *}$ & 1 & & & & & & & & \\
\hline Sağlık Tutum & ,030 &, $712^{* *}$ &, 216 &,- 130 &, 176 & 1 & & & & & & & \\
\hline Gida Tutum &, 038 &, $726^{* *}$ &, $317^{* *}$ &,- 062 &, 122 &, $568^{* *}$ & 1 & & & & & & \\
\hline Tarım Tutum & ,038 &, $747^{* *}$ &, $352^{* *}$ & ,045 & ,018 &, $323^{* *}$ &, $497^{* *}$ & 1 & & & & & \\
\hline Eğitim Tutum & ,043 &,- 203 &, 028 &, 161 &,- 086 &,$- 317^{* *}$ &,$- 432^{* *}$ &,$- 409^{* *}$ & 1 & & & & \\
\hline $\begin{array}{l}\text { Araştırma } \\
\text { Tutum }\end{array}$ & ,195 &, $692^{* *}$ &, 039 &, 136 &, 187 &, $468^{* *}$ &, $337^{* *}$ &, $324^{* *}$ &,- 203 & 1 & & & \\
\hline Mikroorg. Kabul &, 123 &, 216 &, $698^{* *}$ &, 082 &, 121 & ,109 &, 167 &, 120 &, 076 &, 134 & 1 & & \\
\hline Bitki Kabul &,- 080 &, $345^{* *}$ &, $924^{* *}$ &,- 158 &, 023 & ,190 &, $342^{* *}$ &, $383^{* *}$ &,- 019 &,- 031 &, $445^{* *}$ & 1 & \\
\hline Hayvan Kabul &, 019 &, $329^{* *}$ &, $793^{* *}$ &,- 098 &, 126 &, $242^{*}$ &, 217 &, $316^{* *}$ &, 046 &, 036 &, $681^{* *}$ &, $333^{* *}$ & 1 \\
\hline
\end{tabular}

Tablo 6 incelendiğinde adayların GDO toplam tutum ve toplam kabul etme puan ortalamaları arasında $\left(\mathrm{r}_{(67)}=0,367 ; \mathrm{p}<0,01\right)$ istatistiksel olarak bir ilişki bulunurken toplam bilgi ile toplam tutum $\left(\mathrm{r}_{(67)}=0,12 ; \mathrm{p}>0,05\right)$ ve toplam bilgi ile toplam kabul etme puanlar1 $\left(\mathrm{r}_{(67)}=0,002 ; \mathrm{p}>0,05\right)$ arasinda istatistiksel olarak bir ilişki bulunmamıştır. Ayrıca sınıf öğretmeni adaylarının GDO kabul etme toplam puanlar1 ile tarım tutum $\left(\mathrm{r}_{(67)}=0,352 ; \mathrm{p}<0,01\right)$ ve gida tutum $\left(\mathrm{r}_{(67)}=0,317 ; \mathrm{p}<0,01\right)$ puanlar1 arasinda istatistiksel olarak anlamlı bir ilişki bulunmuştur.

\section{Sınıf Öğretmeni Adaylarının Genetiği Değiştirilmiş Organizmalara Yönelik Görüşleri}

Sınıf öğretmeni adaylarının GDO’ya yönelik görüşlerini tespit etmek amacıyla adaylara sorulan açık uçlu soruların içerik analiz sonuçları beş başlık halinde sunulmuştur. Adaylara yöneltilen " $G D O$ nedir?" sorusuna yönelik görüşleri ve frekansları Tablo 7'de verilmiştir.

Adayların GDO'yu en fazla genetiği değiştirilmiş organizma olarak tanımladıkları görülmektedir. Bununla birlikte genleri değiştirilerek oluşturan yeni organizma; doğal yapısı, dokusu bozulmuş ya da değiştirilmiş organizma; genetiği değiştirilerek kötü yönleri ortadan kaldırılan ürün; yeni özelliklerde bir ürün olarak tanımlayan adaylar da bulunmaktadır. Bu bulgulardan adayların GDO kavramını anlamlandırabildikleri, biyoteknoloji uygulamaları ile gerçekleştirilebilecek durumları bildikleri söylenebilir. 
Tablo 7.

Adayların GDO'nun ne olduğuna yönelik görüşleri ve frekansları

\begin{tabular}{llc}
\hline No & Görüşler & f \\
\hline $\mathbf{1}$ & Genetiği değiştirilmiş organizmalardır. & 42 \\
$\mathbf{2}$ & Genleri değiştirilerek oluşturulmuş yeni bir organizmadır. & 7 \\
$\mathbf{3}$ & Doğal yap̧ı, dokusu bozulmuş ya da değiştirilmiş ürünlerdir. & 6 \\
$\mathbf{4}$ & Genetiği değiştirilerek kötü yönleri ortadan kaldırılmış ürünlerdir. & 4 \\
$\mathbf{5}$ & Yeni özellikte bir ürün elde edilmesidir. & 3 \\
$\mathbf{6}$ & Bir organizmanın genini alarak yerine başka bir gen koymadır. & 2 \\
$\mathbf{7}$ & Herhangi bir bitki veya hayvanın DNA’sının değiştirilmesidir. & 2 \\
$\mathbf{8}$ & Çekirdeksiz üzümün DNA'sının karpuza geçirilmesidir. & 1 \\
$\mathbf{9}$ & Fayda sağlayan, kısmen zararlı etkiler yaratan genetiğiyle oynanmış organizmadır. & 1 \\
$\mathbf{1 0}$ & Genetik müdahale yöntemiyle genetik yapısınının bitki, bakteri gibi genlerinin aktarımıyla & 1 \\
& oluşan yeni organizmadır. & 1 \\
$\mathbf{1 2}$ & Islah çalışmasıdır. & 1 \\
\hline
\end{tabular}

Adaylara yöneltilen “GDO’lu ürünlerin hangi alanlarda kullanıldığını düşünüyorsunuz?” sorusuna yönelik görüşleri ve frekansları Tablo 8'de verilmiştir.

Tablo 8.

Adayların GDO’lu ürünlerin kullanıldı̆̆g alanlara yönelik görüşleri ve frekansları

\begin{tabular}{llcc}
\hline Kategoriler & Görüşler & $\mathbf{f}$ & $\sum \mathbf{f}$ \\
\hline \multirow{2}{*}{ Gıda sektörü } & Bitkisel gıdalar & 23 & \\
& Hayvansal gıdalar & 13 & 70 \\
& Gidalarda & 34 & \\
\hline \multirow{2}{*}{ Tarım sektörü } & Tarım / ziraat & 21 & 23 \\
& Tohum üretiminde & 2 & 20 \\
\hline \multirow{2}{*}{ Sağlık sektörü } & Sağlik/ tıp & 2 & 2 \\
& İlaç üretiminde & 2 & \\
\hline
\end{tabular}

Adayların GDO'lu ürünlerin en fazla gıda alanında, daha sonra tarım-ziraat ve son olarak sağliktıp alanında kullanıldığını düşündükleri görülmüştür. Adaylar gıda alanını bitkisel gıdalar, hayvansal gıdalar ve genel olarak gıdalar olarak ifade etmişlerdir. Tarım alanını tarım, ziraat ve tohum üretimi olarak ifade etmişlerdir. Sağlık alanını ise genel sağlık, tıp uygulamaları ve ilaç üretimi olarak ifade etmişlerdir.

Adaylara yöneltilen "GDO'lu ürünler ne amaçla kullanılmaktadır?" sorusuna yönelik görüşleri ve frekansları Tablo 9'da verilmiştir.

Tablo 9.

Adayların GDO’lu ürünlerin kullanılma amaçlarına yönelik görüşleri ve frekansları

\begin{tabular}{llcc}
\hline Kategoriler & Görüsşler & f & $\sum \mathbf{f}$ \\
\hline \multirow{2}{*}{ Verimi arttırmak/ } & Üreticiler tarafindan kâr elde etmek & 13 \\
Kâr elde etmek & Kisa sürede daha fazla ürün üretmek & 11 \\
& Daha az emekle daha çok ürün ve kalite elde etmek (verimi arttırmak) & 10 & 43 \\
& Daha fazla ürün elde etmek & 9 & 21 \\
\hline \multirow{2}{*}{ Tüketiciyi } & Ürünlerin görüntü kalitesini (şekil, parlaklık gibi) arttırmak & 8 & 33 \\
cezbetmek & Ürünleri daha uzun süre saklamak & 4 & \\
\hline İnsanlığın & Farklı özelliklerde ürünler elde etmek (ürün çeşitliliğini arttırmak) & 15 \\
ihtiyaçlarını & Artan nüfusun talebini karşıllamak amacıyla üretim yapmak & 7 & 25 \\
karşlama & Insanlara fayda sağlamak & 3 & \\
\hline
\end{tabular}


Tablo 9 (devami).

Adayların GDO'lu ürünlerin kullanılma amaçlarına yönelik görüşleri ve frekansları

\begin{tabular}{llll}
\hline Kategoriler & Görüsşler & f & $\sum \mathbf{f}$ \\
\hline & Sağlı alanında faydalanmak & 3 \\
Sağlık & Kalıtsal hastalıkları engellemek, bozuk organları iyileştirmek & 2 \\
uygulamaları & Organ donörü ve organların onarımında kullanmak & 2 & 9 \\
& İlaç üretmek & 1 & 1 \\
\hline Yeni pazarlar & Tip alanında tedavi etme amacıyla kullanmak & GDO’lu ürünler aracılığıyla ülkelere hastalık bulaştırmak & 2 \\
oluşturmak & Hastalık bulaştırılan toplumlara ilaç satmak & 1 & 3 \\
\hline Diğer & Bilgim yok & 3 & 3 \\
\hline
\end{tabular}

Adaylar GDO’lu ürünlerin kullanılma amaçlarının en fazla verimi arttırmak ve buradan kâr elde etmek, tüketiciyi cezbetmek ve insanlığın ihtiyaçlarını karșılamak amacıyla kullanıldığını düşünmektedir. Daha sonra ise sağlık uygulamaları ve yeni pazarlar oluşturma amacıyla kullanıldığını düşünen adaylar bulunmaktadır. Çok az sayıda aday ise bilgisinin olmadığını ifade etmiştir. İfadelerin frekansları dikkate alındığında adayların çoğunun GDO'lu ürünlerin ve biyoteknoloji uygulamalarının tüketicileri cezbetmek ve buradan kâr elde etmek amacıyla kullanıldığını ifade etmelerinden, GDO'ların daha çok olumsuz yönlerini gördükleri söylenebilir. Ancak bazı adayların artan nüfusla birlikte insanlığın ihtiyaçlarının karşılanması, kalıtsal hastalıkların tedavi edilmesi, organ donörlerinin sağlanması ve organların iyileştirilmesi amaçlarıyla kullanılabileceği ifadelerinden GDO'ların olumlu yönlerini de gördüğü söylenebilir. Bununla birlikte GDO’lu ürünlerle farklı ülkelere önce hastalık bulaştırmak daha sonra ise bu hastalığı tedavi edecek ilaçları pazarlamak amacıyla üretildiğini düşünen adaylar da bulunmaktadir.

Adaylara yöneltilen “GDO’lu ürünlerin zararları var mıdır?” sorusuna yönelik görüşleri ve frekansları Tablo 10’ da verilmiştir.

Tablo 10.

Adayların GDO'lu ürünlerin zararlarına yönelik görüşleri ve frekansları

\begin{tabular}{|c|c|c|c|}
\hline Kategoriler & Görüşler & $\mathbf{f}$ & $\sum \mathbf{f}$ \\
\hline \multirow{14}{*}{$\begin{array}{l}\text { İnsan } \\
\text { sağlığına } \\
\text { zararları }\end{array}$} & $\begin{array}{l}\text { Genetiği değiștiğinden (doğallığı bozulduğundan) aynı özelliği } \\
\text { göstermeyeceğinden sağlığa zararlıdır. }\end{array}$ & 31 & \multirow{14}{*}{82} \\
\hline & Hastalıklara neden olabilir. & 11 & \\
\hline & $\begin{array}{l}\text { İnsan vücudundaki genlerde zamanla farklılaşmalara (mutasyona) neden } \\
\text { olur. }\end{array}$ & 9 & \\
\hline & Vücudun doğal işleyişini bozar. & 6 & \\
\hline & Yapay olduğu için zamanla vücutta hasar oluşturur. & 6 & \\
\hline & Bazı insanlarda alerjiye neden olabilir. & 5 & \\
\hline & $\begin{array}{l}\text { Daha kaliteli ürün elde etmek için kullanılan ilaçlar insan sağlığına zarar } \\
\text { verir }\end{array}$ & 3 & \\
\hline & Hormonsal bozukluklara neden olabilir. & 3 & \\
\hline & Vücut direnci düşürür. & 2 & \\
\hline & Çocukların gelişimi olumsuz etkilenebilir. & 2 & \\
\hline & Diğer ülkelerden alacağımız ilaçlarla tedavi edilen hastalıklar oluşturur. & 1 & \\
\hline & Daha zor sindirilir. & 1 & \\
\hline & Yağ yapma oranı fazladır. & 1 & \\
\hline & Kanserlerin çoğu GDO’lardan kaynaklanmaktadır. & 1 & \\
\hline \multirow{3}{*}{$\begin{array}{l}\text { Doğallığın } \\
\text { bozulmasına } \\
\text { zararları }\end{array}$} & Orijinal g1danın içeriğinin kalitesi (besin değeri) düşer. & 6 & \multirow{3}{*}{9} \\
\hline & Doğalları kadar lezzetli olmaz. & 2 & \\
\hline & Doğal besinlerin yapısı bozulur. & 1 & \\
\hline \multirow{3}{*}{$\begin{array}{l}\text { Çevreye } \\
\text { zararları }\end{array}$} & Bitkilerin, hayvanların ve insanların sağlığına zarar verir. & 1 & \multirow{3}{*}{4} \\
\hline & Bitkileri ilaçlama toprağı kirletir. & 2 & \\
\hline & Çevreye zararı vardır. & 1 & \\
\hline Diğer & Vardır ama ne tür olduğunu tam olarak bilmiyorum. & 2 & 2 \\
\hline
\end{tabular}


Adayların büyük çoğunluğu GDO'lu ürünlerin en fazla insan sağlığına zararı olduğunu düşünmektedir. Az sayıda aday ise GDO'larla ürünlerin koku, tat gibi doğal özelliklerinin bozulacağını, GDO'ların çevreye zararlarının olduğunu düşünmektedir. Çok az sayıda aday ise GDO'ların zararları olduğuna yönelik bir kanısının olduğunu ancak bu zararların neler olduğunu bilmediğini ifade etmiştir. Ayrıca adaylar sadece GDO'lu ürünlerin genetiğinin değiştirilmesi nedeniyle sağlığa zararlarının olduğunu düşünmektedir. Bu adaylar GDO'lu ürünlerin zararlarını herhangi bir bilimsel nedene veya kanıta dayandıramamaktadır.

Adaylara yöneltilen “GDO’lu ürünlerin faydaları var mıdır?” sorusuna yönelik görüşleri ve frekansları Tablo 11'de verilmiştir.

Tablo 11

Adayların GDO’lu ürünlerin faydalarına yönelik görüşleri ve frekansları

\begin{tabular}{llcc}
\hline Kategoriler & Görüşler & f & $\sum \mathbf{f}$ \\
& Sağlı-Tıp alanında kullanımı faydalı olur. & 11 \\
& İlaç-aşı üretiminde faydalı olur. & 10 \\
İnsan & Organ üretimi ve nakilleri konusunda faydalı olur. & 5 \\
sağlığına & Hastalıkların tedavisinde kullanılır. & 4 & 31 \\
faydaları & Vücudun üretemediği gen veya bakterileri üreterek hastalıkların & 1 \\
& tedavisinde kullanılabilir. & 1 \\
& Hatalı bir geni düzeltebilir. & 4 \\
Gida & Besinleri daha cazip ve kaliteli hale getirir. & 3 \\
kalitesine & Ürünlerin besleyicilik değerleri artar. & 3 \\
faydaları & Ürünler uzun süre dayanabilir. & 1 \\
\hline Tüketiciye & Hastalıklara ve böceklere karşı dirençli ürünler elde edilir. & 5 \\
faydaları & Iz maliyetle fazla ürün elde edilir. & 3 \\
\hline \multirow{2}{*}{$\begin{array}{l}\text { Üreticiye } \\
\text { faydaları }\end{array}$} & Üreticiler için faydalıdır. & 4 \\
\hline \multirow{2}{*}{ Doğaya } & Besin sıkıntısı yaşanan bölgelerde üretimi arttırmak adına faydalı olabilir. & 3 \\
faydaları & Üretimi hızlandırır. & 1 \\
\hline Diğer & Toprağın verimini arttıracak ürünler üretiliyor. & 1 \\
\hline & Tararlı bakterileri yok eder. & 1 \\
\hline
\end{tabular}

Adayların bir kısmı GDO’lu ürünler ve biyoteknoloji uygulamalarının ilaç üretimi, organ üretimi veya onarımı gibi nedenlerden dolayı insan sağlığına faydaları olduğunu düşünmektedir. Ayrıca bazı adaylar; görüntü kalitesi, besleyici olma, uzun süreli saklanabilme nedenlerinden dolayı gıda kalitesini arttırmada ve daha ucuza yaz-kıș gibi farklı zaman dilimlerinde ürün bulma nedenlerinden dolayı tüketici açısından faydalı olduğunu düşünmektedir. Bunlarla birlikte bilgisi olmadığını ve GDO'nun faydasının olmadığını düşünen adaylar da bulunmaktadır.

\section{TARTIŞMA, SONUÇ ve ÖNERILER}

$\mathrm{Bu}$ çalışmada sınıf öğretmeni adaylarının biyoteknoloji uygulamaları temelinde genetiği değiştirilmiş organizmalara yönelik bilgi, tutum ve kabul etme durumlarının likert tipi ölçeklerle belirlenerek bu değişkenler arasındaki ilişkinin incelenmesi ve açık uçlu sorulardan elde edilen nitel bulgularla nicel bulguların desteklenmesi amaçlanmıştır. Çalışmada adayların genetik hakkında temel bilgilere orta düzeyde sahip olduğu, modern biyoteknoloji uygulamaları ile bu teknolojilerin insan ve çevreye zarar ve faydaları hakkında yeterli bilgiye sahip olmadıkları, ayrıca bazı maddelerde yanlış bilgilere sahip oldukları tespit edilmiştir. Adayların bilgi düzeylerinin düşük olduğu bulgusu önceki çalışma bulgularıyla uyumluluk göstermektedir (Ergin ve diğ., 2015; Oğur ve diğ., 2017; Özdemir ve diğ. 2010; Sorgo \& Ambrozic-Dolinsek, 2010; Sürmeli \& Şahin, 2009; Y1lmaz ve diğ. 2015). Bu durumun muhtemel nedeni adayların GDO'ya yönelik ilgilerinin düşük olmasıdır. Bu çalışmada adaylara sorulan "Kendinizi GDO'lu ürünlere karşı ne kadar ilgili hissediyorsunuz?" sorusuna 
verdikleri cevap ortalamasının \%33 olması bu nedeni desteklemektedir. Diğer bir neden ise bu çalışma örneklemini oluşturan sınıf öğretmeni adaylarının biyoloji dersini özellikle biyoteknoloji konularını ortaokul 8 ve lise 9. sınıfta görmüş olmaları daha sonraki süreçte öğretim amaçlı olarak bu konularla karşılaşmamış olmaları olabilir. Ergin ve diğerleri (2015), Haspolat-Kaya ve diğerleri (2013) ile Yılmaz ve diğerleri (2015)'nin çalışmalarında adayların çoğunlukla kısmen bilgi sahibi oldukları bulguları da bu nedenleri destekler niteliktedir. Bazı çalışmalarda katılımcılar GDO bilgisine sahip olduklarını belirtse de (Merdan, 2019; Temelli \& Kurt, 2011; Yanpar, Müftüoğlu, \& Saka, 2017), tıp fakültesi (Ergin ve diğ. 2015; Koçak ve diğ., 2010), fen bilgisi (Çankaya \& Filik-İşçen, 2015; Sönmez \& Kılınç, 2012; Uysal ve diğ., 2018), lise (Gürbüzoğlu-Yalmanc1, 2016) ve ilköğretim (Bilen ve Özel, 2012; Özden ve diğ., 2013) öğrencileri gibi çeşitli örneklemlerle yapılan çalışmalarda katılımcıların GDO bilgi düzeylerinin düşük olması ve bireylerin "kısmen bilgi sahibiyim" şeklindeki ifadeleri toplumların bilinçlendirilmesi amacıyla ciddi bir eğitime ihtiyaç duyulduğunu ortaya koymaktadır. Özden ve diğerleri (2013) 8. sınıf öğrencileriyle yaptıkları çalışmalarında öğrencilerin bazı kavram yanılgılarına sahip olmaları nedeniyle öğrencilere kapsamlı bir eğitim verilmesi gerektiğine yönelik önerileri de bu yorumu desteklemektedir.

Adayların GDO’ya yönelik genel tutumları ve eğitime yönelik tutum hariç diğer alt boyutlarda tutum düzeylerinin düşük olduğu tespit edilmiştir. Eğitime yönelik tutum puanlarının ise yüksek düzeyde olduğu görülmüştür. Adayların GDO'ya yönelik genel tutumlarının düşük olduğu bulgusu önceki çalışma bulgularıyla uyumluluk göstermektedir (Özdemir ve diğ., 2010; Özel ve diğ., 2009; Sorgo \& Ambrozic-Dolinsek, 2009; Sönmez \& Kılınç, 2012). Adayların GDO hakkında düşük düzeyde bir tutuma, diğer bir ifadeyle olumsuz tutuma sahip olmalarının muhtemel nedenleri GDO kavramını daha çok gıdalarla ilişkilendirmeleri, tıp, sağlık uygulamalarını GDO görmemeleri ve bilgi edindikleri internet, televizyon ve toplum içindeki tartışmalarda GDO'nun zararlı yönlerinin daha fazla ön plana çıkması olabilir. Açık uçlu sorulardan elde edilen nitel bulgularda da en fazla, GDO'nun insan sağlığına zararlarının ifade edilmesi bu nedenlerini desteklemektedir. Burada adayların olumsuz tutuma sahip olmasının GDO bilgi düzeylerinin düşük olmasından kaynaklandığı düşünülebilir. Ancak adayların bilgi düzeyleri ile tutumları arasında bir ilişkinin ortaya çıkmaması bilgi düzeyinin tutumu etkilemediğini göstermektedir. Diğer taraftan eğitime yönelik tutumlarının yüksek olması adayların duyarlılığını göstermesi bakımından önemlidir. Bu bulgu Gürbüzoğlu-Yalmancı ve Gözüm (2016) fen bilgisi öğretmen adaylarıyla yaptıkları çalışmalarında adayların eğitime ihtiyaç duyduklarını ve istekli olduklarını ifade etmeleri bulgularıyla uyumluluk göstermektedir.

Adayların GDO'lu ürünleri toplam kabul etme durumlarının düşük düzeyde olduğu, GDO'lu bitkileri kabul etme durumlarının GDO'lu mikroorganizmaları ve hayvanları kabul etme durumlarından daha yüksek düzeyde olduğu tespit edilmiştir. Diğer bir ifadeyle adaylar GDO'lu ürünlerin kullanımını genel olarak kabul etmemektedir. Ayrıca adayların GDO’lu bir ürün türünü kabul etmeleri, diğer ürün türlerini de kabul edecekleri anlamına gelmemektedir. Bu çalışmada bitkilerin, hayvan ve mikroorganizmalara göre adaylar tarafından biraz daha kabul edilebilir olduğu görülmüştür. Adayların toplam kabul etme durumlarının düşük olduğu bulgusu önceki çalıșma bulgularıyla uyumludur (Sorgo \& Ambrozic-Dolinsek, 2009; Sorgo \& Ambrozic-Dolinsek, 2010). Adayların GDO'lu ürünleri kabul etme durumlarının düşük olmasının muhtemel nedeni GDO'ya yönelik tutumlarının düşük olmasıdır. Adayların tutum ve kabul etme durumları arasında anlamlı bir ilişkinin olduğu bulgusu bu nedeni desteklemektedir.

Adayların GDO toplam tutum ve toplam kabul etme durumları arasında bir ilişki bulunurken, toplam bilgi ile toplam tutum ve toplam bilgi ile toplam kabul etme puanları arasinda istatistiksel olarak bir ilişsi bulunmamıştır. Adayların tutum ve kabul etme durumları arasında bir ilişki olduğu ve diğer değişkenler arasında ilişki olmadığı bulgusu önceki çalışma bulgularıyla uyumludur (Sorgo \& Ambrozic-Dolinsek, 2010). Adayların bilgi ve kabul etme durumları arasında anlamlı bir ilişkinin bulunmaması adayların GDO hakkında kararlarını verirken bilimsel bilgileri dikkate almak yerine kulaktan dolma bilgileri dikkate aldıklarını göstermektedir. Adayların bilimsel bilgiden ziyade kaynağının ve doğruluğunun kesin olmadığı bilgileri daha fazla dikkate alması diğer sosyobilimsel konular hakkında adayların bilgileri ve tutumlarını araştıran çalışma bulgularıyla da uyumludur (Sadler \& Zeidler, 2005; Sorgo \& Ambrozic-Dolinsek, 2009). 
Açık uçlu sorulardan elde edilen bulgular, adayların GDO kavramının anlamını bildiklerini, çoğunlukla GDO'nun gıda sektöründe kullanıldığını ve üreticiler tarafindan ürünlerin verimini arttırarak kâr elde etmek amacıyla kullanıldığını düşündüklerini ortaya koymuştur. Adaylar GDO'ları en fazla insan sağlığına verdiği zararlar nedeniyle riskli olarak görürken özellikle ilaç ve tıp alanında hastalıkların iyileştirilmesinde ve besin kıtlığının yaşandığı yerlerde gıda ihtiyacının karşılanmasında faydalı olacağı düşüncesinden bazı GDO'lu ürünlerin kabul edilebilir olduğunu düşünmektedir. Bununla birlikte adayların GDO'yu en fazla bitkisel gidalar ile özdeşleştirdikleri ortaya çıkmıştır. Bu bulgular lise öğrencileriyle (Bilen \& Özel, 2012; Gürbüzoğlu-Yalmancı, 2016; Özel ve dĭğ., 2009) ve üniversite öğrencileriyle (Çankaya \& Filik-İ̧şen, 2015; Merdan, 2019; Oğur ve diğ., 2017; Uzunkol, 2012) yapılan çalışmalarda elde edilen bulgular ile uyumluluk göstermektedir. Bu çalışma ve önceki çalışmalarda ortaya konulan, adayların GDO kavramını gıda sektörüyle özdeşleştirip diğer sektörlerle daha az ilgili olduğunu düşünmeleri sonucunun muhtemel nedeni; adayların GDO bilgisini aldıkları TV programları ve internet ortamlarında gıdalar ve zararlı etkileri üzerinde daha çok durulması olabilir. Hem adaylarının bilgilerinin yetersiz olması hem de eğitime yönelik tutumlarının yüksek olması, derslerde GDO ve biyoteknolojiye daha fazla yer verilmesi gerektiğini ortaya koymaktadır.

Adayların tüm toplumu ilgilendiren ve oldukça tartışmalı olan GDO konusunda bilgi, tutum ve kabul etme durumlarının düşük olmasının yanı sıra eğitimin gerekliliğine yönelik tutumun yüksek olması; adayların modern biyoteknoloji uygulamaları ve olası sonuçları hakkında bilgilendirilmesi gerektiğini ortaya koymaktadır. Adayların bilgi, tutum ve kabul etme durumlarının bu kadar düşük olmasının muhtemel nedenleri; nitel bulgularla da ortaya konulan GDO'yu bitkisel gidalarla sinırlı görmeleri, ilgilerinin düşük olması ve GDO hakkında bilgiyi daha çok TV programları ve internet gibi ortamlardan elde etmeleri olabilir. Bu muhtemel durumlar adayların GDO hakkında sağlıklı bilgiler elde edememelerinin yanı sıra yanlış bilgilere sahip olmalarına da neden olmuştur. Eğitime yönelik tutum puanlarının yüksek olması yani bilgilendirmeye ihtiyaçlarının olduğunu dile getirmeleri de bu nedenleri desteklemektedir. Ayrıca adayların bilgi düzeylerinin düşük olması ve bazı maddelerde adayların yarısından fazlasının yanlış bilgiye sahip olması da GDO hakkında bilimsel bir eğitime ihtiyaçları olduğunu desteklemektedir. Ayrıca bu sonuçlar bu çalışmada elde edilen bulguların birbiriyle tutarlı olduğunu göstermektedir. Çalışmada elde bulguların önceki çalışma bulgularıyla tartışılması sonucunda aşağıdaki öneriler getirilmiştir:

1. Öğretmen adaylarının GDO hakkında bilgi düzeyleri oldukça düşüktür, hatta adaylar yanlış bilgilere sahiptirler. Ayrıca adaylar eğitime yönelik olumlu bir tutuma sahiptir. Bu nedenle adayların bilgi düzeylerinin arttırılması amacıyla fakültedeki derslerinde biyoteknoloji uygulamalarıyla birlikte GDO ile ilgili konulara daha fazla yer verilmelidir.

2. Sınıf öğretmeni adaylarının GDO bilgi düzeyleri ile tutum ve kabul etme durumları arasında anlamlı bir ilişkinin olmadığının ortaya konulması nedeniyle daha sonra yapılacak çalışmalarda adayların GDO'ya yönelik tutumlarını etkileyen faktörlerin derinlemesine incelenmesi faydalı olacaktır.

3. Sınıf öğretmeni adayları GDO kavramını daha çok gıda sektörüyle ilgili ürünlerle özdeşleştirmektedir. Bu nedenle adaylara GDO ile ilgili verilen ders veya bilgilendirmelerde GDO ve biyoteknoloji kavramları çok yönlü olarak ele alınmalıdır.

4. Adayların GDO'ya yönelik ilgi düzeyleri oldukça düşüktür. Daha bilinçli ve duyarlı toplumların yetişmesinde sınıf ögretmenlerinin etkisinin oldukça fazla olmasından adayların toplumu ilgilendiren sosyobilimsel konularla ilgili olarak farkındalıklarını arttırıcı faaliyetler üzerinde durulmalıdır.

\section{KAYNAKÇA}

Adana, F., Gezer, N., \& Öğüt, S. (2014). Sağlık yüksekokulu öğrencilerinin genetiği değiştirilmiş organizmalara ilişkin bilgi ve görüşleri. Acıbadem Üniversitesi Să̆lık Bilimleri Dergisi, 5(4), 276-280.

Akçay, S. (2017). Öğretmen adaylarının genetiği değiştirilmiş gıdalar ile ilgili algıları. Necatibey Eğitim Fakültesi Elektronik Fen ve Matematik Ĕ̈itimi Dergisi (EFMED), 11(2), 365-382. 
Akkoyunlu, B., Yılmaz-Soylu, M., \& Çağlar, M. (2010). Üniversite öğrencileri için "sayısal yetkinlik ölçeği”" geliştirme çalışması. Hacettepe Üniversitesi Eğitim Fakültesi Dergisi, 39, 10-19.

Aktaş, İ. (2019). Sinıf öğretmeni adaylarının genetiği değiştirilmiş organizmalara yönelik bilgi, tutum ve kabul etme durumlarının incelenmesi. 3. Ulusal Biyoloji Eğitimi Kongresi. 21-22 Aralık, Rize.

Alberts, B.M., \& Labov, J.B. (2003). The future of biotechnology depends on quality science education. Electronic Journal of Biotechnology, 6(3), 167-167.

Bilen, K., \& Özel, M. (2012). Üstün yetenekli öğrencilerin biyoteknolojiye yönelik bilgileri ve tutumları. Necatibey Eğitim Fakültesi Elektronik Fen ve Matematik Ĕgitimi Dergisi (EFMED), 6(2), 135-152.

Büyüköztürk, Ş. (2009). Sosyal bilimler için veri analizi el kitabı. (10. Bask1). Ankara: Pegem Akademi.

Christoph, I.B., Bruhn, M., \& Roosen, J. (2008). Knowledge, attitudes towards and acceptability of genetic modification in Germany. Appetite, 51(1), 58-68.

Çankaya, C., \& Filik-İş̧en, C. (2015). Fen bilgisi öğretmen adaylarının genetiği değiştirilmiş̧ organizmalara (gdo) dair bilgi düzeylerinin ve görüşlerinin belirlenmesi. The Journal of Academic Social Science Studies, 32, 537-554.

Çapık, C., Gözüm, S., \& Aksayan, S. (2018). Kültürlerarası ölçek uyarlama aşamaları, dil ve kültür uyarlaması: Güncellenmiş rehber. Florence Nightingale Journal of Nursing, 26(3), 199-210.

Çelik, V., \& Turgut-Balık, D. (2007). Genetiği değiştirilmiş organizmalar (GDO). Erciyes Üniversitesi Fen Bilimleri Enstitüsü Dergisi, 23(1-2), 13-23.

Dawe, D., Robertson, R., \& Unnevehr, L. (2002). Golden rice: what role could it play in alleviation of vitamin a deficiency? Food Policy, 27(5-6), 541-560.

Dawson, V. (2007). An exploration of high school (12-17 year old) students' understandings of, and attitudes towards biotechnology processes. Research in Science Education, 39, 59-73.

Ergin, A., Uzun, S.U., \& Bozkurt, A.İ. (2015). Pamukkale üniversitesi tıp fakültesi öğrencilerinin genetiği değiştirilmiş organizmalarla ilgili bilgi ve görüşleri. Pamukkale Tip Dergisi, 8(2), 92-98.

Februhartanty, J., Widyastuti, T.N., \& Iswarawanti, D.N. (2007). Attitudes of agricultural scientists in Indonesia towards genetically modified foods. Asia Pacific Journal of Clinical Nutrition, 16(2), 375-380.

Fraenkel, J.R., Wallen, N.E., \& Hyun, H.H. (2012). How to Design and Evaluate Research in Education (8th ed). New York: McGraw Hill Higher Education.

Gürbüzoğlu-Yalmancı, S. (2016). Lise öğrencilerinin genetiği değiştirilmiş organizmalara yönelik algılarının belirlenmesi. Mehmet Akif Ersoy Üniversitesi Eğitim Fakültesi Dergisi, 37, 89-111.

Gürbüzoğlu-Yalmancı, S., \& Gözüm, A.İ.C. (2016). Fen bilgisi öğretmen adaylarının (gdo) sosyo-bilimsel konusuna yönelik araştırma davranışlarının incelenmesi. Ahi Evran Üniversitesi Kırşehir Eğitim Fakültesi Dergisi, 17(1), 499-515.

Hanegan, N.L., \& Bigler, A. (2009). Infusing authentic inquiry into biotechnology. Journal of Science Education and Technology, 18(5), 393-401.

Haspolat-Kaya, I., Konar, N., Poyrazoğlu, E.S., \& Artık, N. (2013). Genetik modifikasyon ve Türk tüketicilerkentli tüketicilerin genetik modifiye organizma ve gıdalara yönelik farkındalıkları. Ankara Üniversitesi Veteriner Fakültesi Dergisi, 60, 213-220.

Hıdıroğlu, S., Önsüz, M.F., Kalafat, C.E., \& Karavuş, M. (2013). Ümraniye İlçesinde 1. basamakta sağlık kuruluşlarına başvuran hastaların genetiği değiştirilmiş organizmalar konusunda bilgi, tutum ve davranışları. Fırat Tip Dergisi, 18(3), 176-181.

Koçak, N., Türker, T., Kılıç, S., \& Hasde, M. (2010). Tıp fakültesi öğrencilerinin genetiği değiștirilmiş organizmalar hakkındaki bilgi, tutum ve davranışlarının belirlenmesi. Gülhane Tip Dergisi, 52, 198-204.

Lazarowitz, R., \& Bloch, I. (2005). Awareness of societal issues among high school biology teachers teaching genetics. Journal of Science Education and Technology, 14(5-6), 437-457.

Merdan, K. (2019). Üniversite öğrencilerinin genetiği değiş̧tirilmiş (trangenik) ürünlere yönelik bilgi düzeyleri ve bakış açılarının belirlenmesi: Gümüşhane üniversitesi örneği. Ufuk Üniversitesi Sosyal Bilimler Enstitüsü Dergisi, 8(15), 343-365.

Miyabe, M., \& Yoshino, T. (2015). Evaluation of the validity of back-translation as a method of assessing the accuracy of machine translation. International Conference on Culture and Computing (Culture Computing), Kyoto, pp. 145-150.

Oğur, S., Aksoy, A., \& Yılmaz, Z. (2017). Üniversite öğrencilerinin genetiği değiştirilmiş organizmalar ve gıdalar hakkındaki bilgi düzeyleri ve tutumları: Bitlis Eren Üniversitesi örneği. Journal of Food and Health Sciences, 3(3), 97-108. 
Özdemir, O., Güneş, M.H., \& Demir, S. (2010). Üniversite öğrencilerinin genetiği değiştirilmiş organizmalara (gdo'lara) yönelik bilgi düzeyleri, tutumları ve sürdürülebilir tüketim eğitimi açısından değerlendirilmesi. Ondokuz Mayls Üniversitesi Ĕgitim Fakültesi Dergisi, 29(1), 53-68.

Özden, M., Akgün, A., Çinici, A., Gülmez, H., \& Demirtaş, F. (2013). 8. sınıf öğrencilerinin genetiği değiştirilmiş organizmalar (gdo) hakkındaki bilgi düzeyleri ve biyoteknolojiye yönelik tutumlarının incelenmesi. Adlyaman Üniversitesi Fen Bilimleri Dergisi, 3(2), 94-115.

Özel, M., Erdoğan, M., Uşak, M., \& Prokop, P. (2009). Lise öğrencilerinin biyoteknoloji uygulamalarına yönelik bilgileri ve tutumları. Kuram ve Uygulamada Eğitim Bilimleri, 9(1), 297-328.

Prokop, P., Leskova, A., Kubiatko, M., \& Diran, C. (2007). Slovakian students' knowledge of and attitudes toward biotechnology. International Journal of Science Education, 29(7), 895-907.

Sadler, T.D., \& Zeidler, D.L. (2005). Patterns of informal reasoning in the context of socioscientific decision making. Journal of Research in Science Teaching, 42(1), 112-138.

Sorgo, A., \& Ambrozic-Dolinsek, J. (2009). The relationship among knowledge of attitudes toward and acceptance of genetically modified organisms (GMOs) among Slovenian teachers. Electronic Journal of Biotechnology, 12(4), 1-13.

Sorgo, A., \& Ambrozic-Dolinsek, J. (2010). Knowlege of, attitudes toward, and acceptance of genetically modified organisms among prospective teachers of biology, home economics, and grade school in Slovenia. Biochemistry and Molecular Biology Education, 38(3), 141-150.

Sönmez, A., \& K1lınç, A. (2012). Preservice science teachers' self-efficacy beliefs about teaching GM Foods: The potential effects of some psychometric factors. Necatibey Faculty of Education Electronic Journal of Science and Mathematics Education, 6(2), 49-76.

Sürmeli, H., \& Şahin, F. (2009). Üniversite öğrencilerinin biyoteknoloji çalışmalarına yönelik bilgi ve görüşleri. Çukurova Üniversitesi Eğitim Fakültesi Dergisi, 3(37), 33-45.

Taş, M., Balc1, M., Yüksel, A., \& Şahin-Yesilçubuk, N. (2015). Consumer awareness, perception and attitudes towards genetically modi-fied foods in Turkey. British Food Journal, 117(5), 1426-1439.

Temelli, A., \& Kurt, M. (2011). Üniversite öğrencilerinin transgenik ürünler (gdo) konusundaki bilgi ve görüşlerinin belirlenmesi. Kuramsal Eğitimbilim, 4(2), 247- 261.

Uşak, M., Erdogan, M., Prokop, P., \& Özel, M. (2009). High school and university students' knowledge and attitudes regarding biotechnology: A Turkish experience. Biochemistry and Molecular Biology Education, 37(2), 123-130.

Uysal, E., Cebesoy, Ü. B. \& Karışan, D. (2018). Fen Bilgisi öğretmen adaylarının genetik uygulamalarına yönelik tutumlarının çeşitli değişkenler açısından incelenmesi. Batı Anadolu Eğitim Bilimleri Dergisi, 9(1), 1-14.

Uzunkol, E. (2012). Sınıf öğretmeni adaylarının genetiği değiştirilmiş organizmalara (gdo) ilişkin algılarının metaforlar aracılığıyla analizi. Ĕgitim ve Öğretim Araştırmaları Dergisi, 1(4), 94-101.

Yanpar, H., Müftüoğlu, S., \& Saka, M. (2017). Ankara'da Yaşayan Üniversite Öğrencilerinin Genetiği Değiştirilmiş Organizmalar İle İlgili Bakış Açısının Değerlendirilmesi, Adnan Menderes Üniversitesi Sağglık Bilimleri Fakültesi Dergisi, 2(1), 12-20.

Yıldırım, A., \& Şimşek, H. (2011). Sosyal Bilimlerde Nitel Araştırma Yöntemleri. Ankara: Seçkin.

Yılmaz, B., Üner, A.K., \& Ercan, A. (2015). Üniversite öğrencilerinin biyoteknoloji ve genetiği değiştirilmiş gidalar ile ilgili tutumları. Akademik Gastroenteroloji Dergisi, 14(2), 64-71. 